\title{
The block to transcriptional elongation within the human c-myc gene is determined in the promoter-proximal region
}

\author{
Anton Krumm, ${ }^{1}$ Tea Meulia, ${ }^{1}$ Mark Brunvand, ${ }^{1}$ and Mark Groudine ${ }^{1,2,3}$ \\ ${ }^{1}$ Division of Basic Sciences, Fred Hutchinson Cancer Research Center, Seattle, Washington 98104 USA; ${ }^{2}$ Department of \\ Radiation Oncology, University of Washington School of Medicine, Seattle, Washington 98195 USA
}

\begin{abstract}
A conditional block to transcriptional elongation is an important mechanism for regulating c-myc gene expression. This elongation block within the first c-myc exon was defined originally in mammalian cells by nuclear run-on transcription analyses. Subsequent oocyte injection and in vitro transcription analyses suggested that sequences near the end of the first c-myc exon are sites of attenuation and/or premature termination. We report here that the mapping of single stranded DNA in vivo with potassium permanganate $\left(\mathrm{KMnO}_{4}\right)$ and nuclear run-on transcription assays reveal that polymerase is paused near position +30 relative to the major c-myc transcription initiation site. Deletion of $350 \mathrm{bp}$, including the sites of 3 '-end formation and intrinsic termination defined in oocyte injection and in vitro transcription assays does not affect the pausing of polymerase in the promoter-proximal region. In addition, sequences upstream of +47 are sufficient to confer the promoter-proximal pausing of polymerases and to generate the polarity of transcription farther downstream. Thus, the promoter-proximal pausing of RNA polymerase II complexes accounts for the block to elongation within the c-myc gene in mammalian cells. We speculate that modification of polymerase complexes at the promoter-proximal pause site may determine whether polymerases can read through intrinsic sites of termination farther downstream.
\end{abstract}

[Key words: Transcriptional elongation; attenuation/termination; RNA polymerase II pausing; human c-myc gene; potassium permanganate $\left.\left(\mathrm{KMnO}_{4}\right)\right]$

Received July 6, 1992; revised version accepted August 21, 1992.

Although control at the level of transcriptional elongation is a well-established mode of gene regulation in prokaryotes (for review, see Yanofsky 1988), only recently has this mechanism been recognized in eukaryotic cells (for review, see Spencer and Groudine 1990). Viral transcription units, including SV40, adenovirus, and the murine minute virus provided the first examples of premature termination or attenuation in eukaryotes (Hay et al. 1982; Ben-Aser and Aloni 1984; Maderious and Chen-Kiang 1984). Control at the level of elongation has also been observed in several eukaryotic cellular genes, including c-myc, c-myb, c-fos, ADA, l-myc, and histone 3.3, and in the human retroviruses HIV-1 and HIV-2 (Spencer and Groudine 1990). For example, the reduction in the steady-state c-myc RNA observed during differentiation of different cell types was shown to result from a reduction in the number of polymerases that read through sites of termination or pausing within exon 1. This conditional elongation block was demonstrated originally by nuclear run-on transcription assays, in which exon 1 transcription signals were higher than intron 1 signals (Bentley and Groudine 1986; Eick and

${ }^{3}$ Corresponding author.
Bornkamm 1986; Nepveu and Marcu 1986). Although truncated c-myc transcripts with 3 ' ends within the first exon or intron could not be detected in mammalian cells, such transcripts are found after injection of the human or murine c-myc genes into Xenopus oocytes (Bentley and Groudine 1988) and in in vitro transcription assays (Kerppola and Kane 1988; London et al. 1991). The $3^{\prime}$ ends of the most prominent of these RNAs map to two $\mathrm{T}$ stretches near the exon 1 /intron 1 boundary, at positions +371 and +421 from the transcription initiation site of the major c-myc promoter (P2). These T-rich sequences are preceded by regions of dyad symmetry that resemble $\rho$-independent bacterial terminators (Eick and Bornkamm 1986). Cassettes containing the dyad symmetry have been shown to function as sites of $3^{\prime}$-end formation and intrinsic termination when cloned downstream of some heterologous promoters (Bentley and Groudine 1988; London et al 1991). However, it has not been demonstrated formally that the $3^{\prime}$ ends of the truncated c-myc RNAs observed in oocytes or in vitro correspond to the sites of the elongation block observed by nuclear run-on transcription assays in mammalian cells.

The transient pausing of RNA polymerase has been suggested to be a prerequisite for termination (or attenuation) (Platt 1986). Therefore, the mapping of single- 
stranded regions within the c-myc gene might identify sites where transcriptional elongation is blocked. Potassium permanganate $\left(\mathrm{KMnO}_{4}\right)$, which oxidizes $\mathrm{T}$ residues in single-stranded DNA very rapidly but is slow to react with double-stranded DNA, is a useful probe for nonbase-paired regions in DNA (Borowiec et al. 1987). The differential reactivity to $\mathrm{KMnO}_{4}$ has been exploited in a variety of studies in which the in vitro and in vivo formation of open complexes has been analyzed in prokaryotic and eukaryotic promoters (Sasse-Dwight and Gralla 19881989 1990; O'Halloran et al. 1989; Zhang and Gralla 1989; Kassavetis et al. 1990; Vos et al. 1991). Recently, Wang et al. (1992) showed that $\mathrm{KMnO}_{4}$ can detect "transcription bubbles" generated in vitro when ternary RNA polymerase II complexes are stalled. In addition, this reagent has been used to detect the pausing of RNA polymerase at the qut site in phage $\lambda$ (Kainz and Roberts 1992).

In the studies reported below, we combine $\mathrm{KMnO}_{4}$ treatment of cells with the in vivo footprinting method based on ligation-mediated polymerase chain reaction (PCR) (Mueller and Wold 1989) to map single stranded regions within the human c-myc gene in vivo. Our analysis reveals that $T$ residues centering at position +30 relative to the major $c-m y c$ transcription initiation site are single stranded in conformation in both proliferating and differentiated cells, whereas the $T$ residues near the exon 1 /intron 1 boundary show no greater reactivity to $\mathrm{KMnO}_{4}$ than control DNA exposed to $\mathrm{KMnO}_{4}$ in vitro. Nuclear run-on transcription assays reveal that RNA polymerase II complexes are paused in this promoterproximal region and that the $\mathrm{KMnO}_{4}$ sensitivity of the $\mathrm{T}$ residue at position +30 is lost when polymerases are released from the promoter-proximal region. Functional assays demonstrate that the promoter-proximal pausing of polymerase is not affected by the deletion of the sequences that program 3 '-end formation and termination in oocyte injection and in vitro transcription assays. In addition, c-myc sequences upstream of +47 are sufficient to generate the polarity of transcription observed in the run-on assays. We speculate that the modification of polymerase complexes at the promoter-proximal site may determine whether polymerases can read through intrinsic sites of termination farther downstream.

\section{Results}

\section{A potential promoter-proximal pause site revealed in vivo by $\mathrm{KMnO}_{4}$}

As described in the introductory section, the positions of open promoter complexes and paused RNA polymerases have been determined by the $\mathrm{KMnO}_{4}$-mapping of singlestranded DNA regions of transcription bubbles in in vitro transcription systems and in prokaryotes in vivo. Thus, we determined whether the $\mathrm{KMnO}_{4}$ assay could be extended to map the in vivo position of attenuated/ paused polymerases within the first exon of the human c-myc gene. We performed the inititial $\mathrm{KMnO}_{4}$ assays in
HL60 cells in which the c-myc gene is amplified approximately 10-fold (Collins and Groudine 1982; Dalla-Favera et al. 1982; for review, see in Collins 1987). During differentiation of the human HL60 cell line into granulocytes or macrophages, the down-regulation of c-myc steady-state RNA occurs in consecutive steps (for review, see Spencer and Groudine 1991). Exposure of HL60 cells to the differentiation-inducing agent retinoic acid (RA) for several hours results in a reduction in the amount of steady-state c-myc RNA by an increase in the block to transcription elongation. After extended exposure to RA for $>2$ days, the frequency of transcription initiation is reduced, and very little or no c-myc transcription initiation is detected when RA treatment is continued for 7 days.

Proliferating HL60 cells and cells induced to differentiate for 2 and 7 days were exposed to $\mathrm{KMnO}_{4}$, and the modified DNA was used in the in vivo footprinting assay (see Materials and methods). The pattern of $\mathrm{KMnO}_{4}$ sensitivity observed in vivo was also compared with that obtained after exposure of purified genomic DNA to $\mathrm{KMnO}_{4}$ in vitro. Surprisingly, comparison of the patterns of $\mathrm{KMnO}_{4}$ sensitivity in the region of the exon 1 /intron 1 boundary (Fig. 1) revealed only minor differences among the in vitro-modified DNA ( $T$ lane) and DNA from proliferating (prol lane) and differentiated (RA $48 \mathrm{~h}$ and RA $7 \mathrm{~d}$ lanes) cells. None of the observed minor differences fulfilled the requirements of a potential pause site. For example, some sites persisted in cells differentiated for 7 days, at which time $\mathrm{c}-m y c$ transcription is not detectable by nuclear run-on transcription assays (Bentley and Groudine 1986; A. Krumm, unpubl.). In addition, these cells also displayed specific $\mathrm{KMnO}_{4}$ sensitive sites that were not detectable in naked DNA, proliferating cells, or cells differentiated for $48 \mathrm{hr}$. The significance of these sites in the transcriptionally inert HL60 cells differentiated for 7 days is unclear; such changes may reflect alterations in the topology of the $c-m y c$ gene associated with changes in the chromatin structure of the locus observed after prolonged exposure of HL60 cells to differentiation agents (Siebenlist et al. 1988).

In vivo footprinting of the entire first exon, however, revealed that a region $30 \mathrm{bp}$ downstream of the c-myc P2 transcription initiation site was highly sensitive to $\mathrm{KMnO}_{4}$. As shown in Figure. 2, A and $\mathrm{B}$, the $\mathrm{T}$ residue at +30 of the noncoding strand is hypersensitive to $\mathrm{KMnO}_{4}$ in both proliferating cells (prol lanes) and cells induced to differentiate for 1 (RA $24 \mathrm{~h}$ lanes) or two (RA $48 \mathrm{~h}$ lanes) days but is not sensitive in the in vitro-modified DNA sample ( $T$ lane). This implies that these sequences are in a single-stranded conformation in vivo. The hypersensitivity at this position is dependent on the transcriptional activity of the c-myc gene, because RA treatment for 7 days results in complete loss of $\mathrm{KMnO}_{4}$ hypersensitivity at this position (see RA $7 \mathrm{~d}$ lane). We have also observed that the $\mathrm{T}$ residue at +30 is hypersensitive to $\mathrm{KMnO}_{4}$ in HeLa cells, in which c-myc transcription is high and the c-myc gene is not amplified (data not shown). Analysis of $\mathrm{KMnO}_{4}$ sensitivity of the 

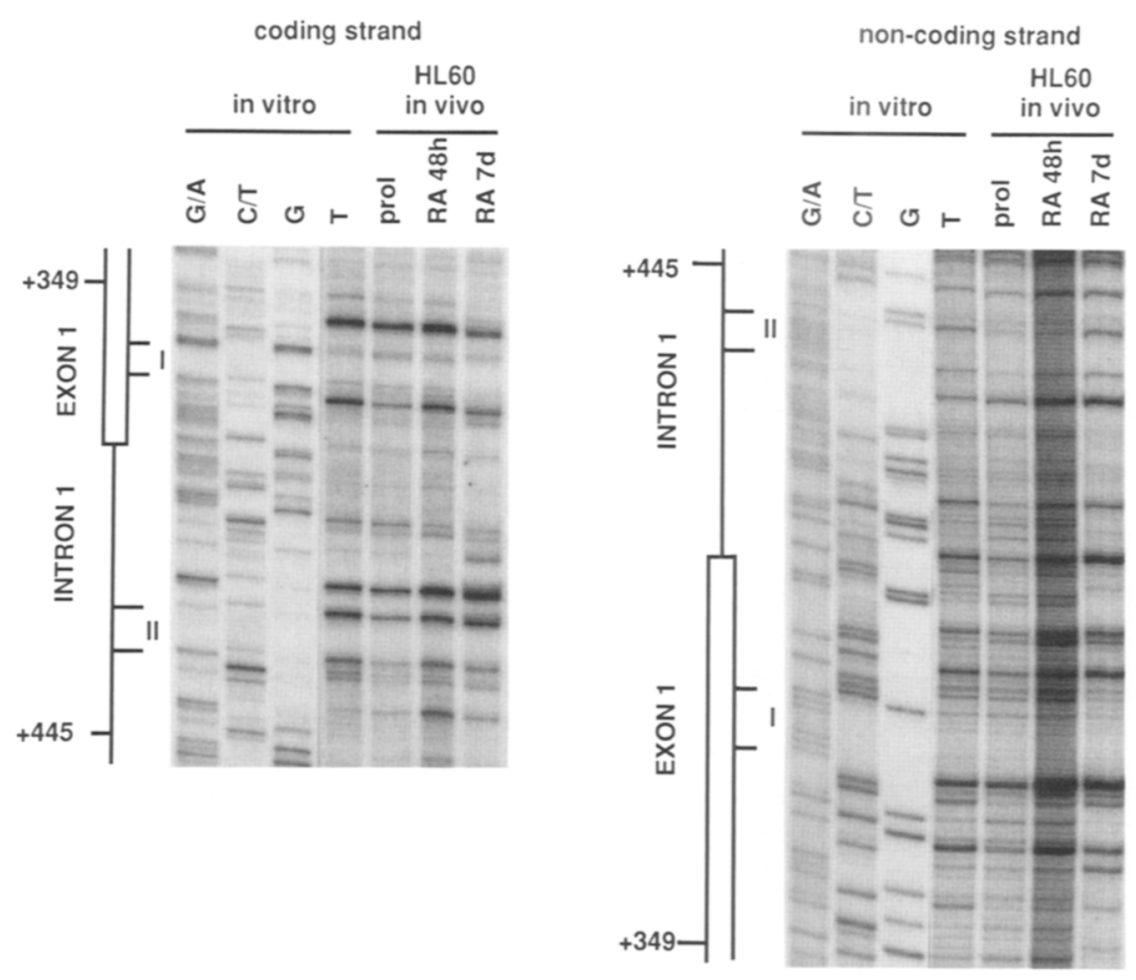

Figure 1. In vivo footprinting of potassium permanganate $\left(\mathrm{KMnO}_{4}\right)$-sensitive sites at the c-myc exon $1 /$ intron 1 boundary. The pattern of $\mathrm{KMnO}_{4}$-sensitive residues on both coding and noncoding strands in proliferating (prol) cells and cells differentiated with RA for $48 \mathrm{hr}$ (RA $48 \mathrm{~h}$ ) and 7 days (RA 7d) were compared with genomic DNA treated with $\mathrm{KMnO}_{4}$ in vitro. $G / A, G$, and $C / T$ sequence ladders are derived from genomic DNA treated in vitro with formic acid $(G / A)$, dimethylsulfate $(G)$, or hydrazine $(C / T)$. No major differences in $\mathrm{KMnO}_{4}$ sensitivity among the in vitro-treated DNA and in vivo-treated proliferating cells and cells differentiated in the presence of RA for 48 $\mathrm{hr}$ are detected within positions +349 to +445 relative to the $\mathrm{P} 2$ promoter start site. The minor changes in ratios of bands observed in proliferating cells and cells induced for $48 \mathrm{hr}$ vary in different experiments and are not considered significant. Significant differences from the pattern of $\mathrm{KMnO}_{4}$ obtained in vitro are detected only in cells differentiated in the presence of RA for 7 days, at which time c-myc transcription initiation is undetectable.

coding strand within the promoter region was uninformative owing to the lack of $T$ residues within the +17 to +55 region (Fig. $2 \mathrm{C}$ ).

The pattern of $\mathrm{KMnO}_{4}$ sensitivity around position +30 (summarized in Fig. $2 \mathrm{C}$ ) was not identical in cells at different stages within the HL60 differentiation pathway. In proliferating HL60 cells, T residues at positions $+24,+26,+36$ and +40 are also hypersensitive to $\mathrm{KMnO}_{4}$, whereas the sensitivity of these residues is diminished in cells induced for $48 \mathrm{hr}$ with RA (Fig. 2B cf. prol and RA 48h lanes). Cells induced for $24 \mathrm{hr}$ (RA 24h lanes) display an intermediate pattern, with a lowered sensitivity to $\mathrm{KMnO}_{4}$ at positions surrounding +30 . The differential sensitivity of $\mathrm{T}$ residues may reflect differences in RNA polymerase complexes or differences in the nature of pausing/termination reactions (see below).

In addition to the hypersensitivity detected downstream of the $\mathrm{P} 2$ transcription initiation site, $\mathrm{T}$ residues at positions $-40,-44$, and -48 were consistently hyposensitive (less reactive) to $\mathrm{KMnO}_{4}$ in cells induced with RA for $48 \mathrm{hr}$ or longer, and a $\mathrm{C}$ residue at -37 was hypersensitive in cells induced for $48 \mathrm{hr}$ (Fig. 2B, cf. prol and RA 24h lanes with RA 48h lanes in the MElal region). The basis of these differential sensitivites in the upstream region of the promoter is not clear; however, the region defined by these residues corresponds to the MElal site of protein-DNA interaction in vitro (see Discussion; Asselin et al. 1989; Pyrc et al. 1992 ).

The c-myc elongation block is due to the promoterproximal pausing of polymerase

If the single-stranded region revealed by the $\mathrm{KMnO}_{4}$ as- say is the result of the pausing of polymerase II complexes downstream of the transcription initiation site, a higher density of polymerase molecules would be expected in this region. Thus, the pausing of ternary complexes in proliferating and differentiated HL60 cells was further analyzed in nuclear run-on assays in which polymerase II continues to elongate in isolated nuclei in the presence of $\left[{ }^{32} \mathrm{P}\right] \mathrm{UTP}$. The amount of ${ }^{32} \mathrm{P}$-labeled RNA transcripts hybridizing to membrane-bound, singlestranded DNA is proportional to the density of elongating polymerase II molecules and the $U$ content of the probes (Bentley and Groudine 1986). The location within the $c-m y c$ gene and $U$ content of the probes used for these studies is shown in Figure 3A. In analyzing the results of each experiment, the signal derived from the hybridization of nascent transcripts to each c-myc probe was corrected for the $U$ content of the probes and normalized to the transcription signal of the $\mathrm{H} 2 \mathrm{~B}$ gene, which provides an internal standard (Fig. 3C, H2B-normalized graph). The relative distribution of polymerases within the $c-m y c$ regions corresponding to the individual probes is also presented (Fig. 3D, self-corrected graph).

Nuclear run-on transcription assays were performed under low (37.5 to $75 \mathrm{~mm} \mathrm{KCL}$ ) and high (150 mM KCl) salt conditions, and in the presence of Sarkosyl. Both high salt and Sarkosyl have been shown to release polymerase complexes arrested at the Drosophila hsp 70 gene promoter into sites farther downstream (Rougvie and Lis 1988; O'Brien and Lis 1991). Whereas transcription of the $c-m y c$ gene is low in nuclei of both proliferating and differentiating cells under low salt conditions, a disproportionally strong increase in signal of promoter-proximal sequences at +47 to +169 (NS probe) is observed 


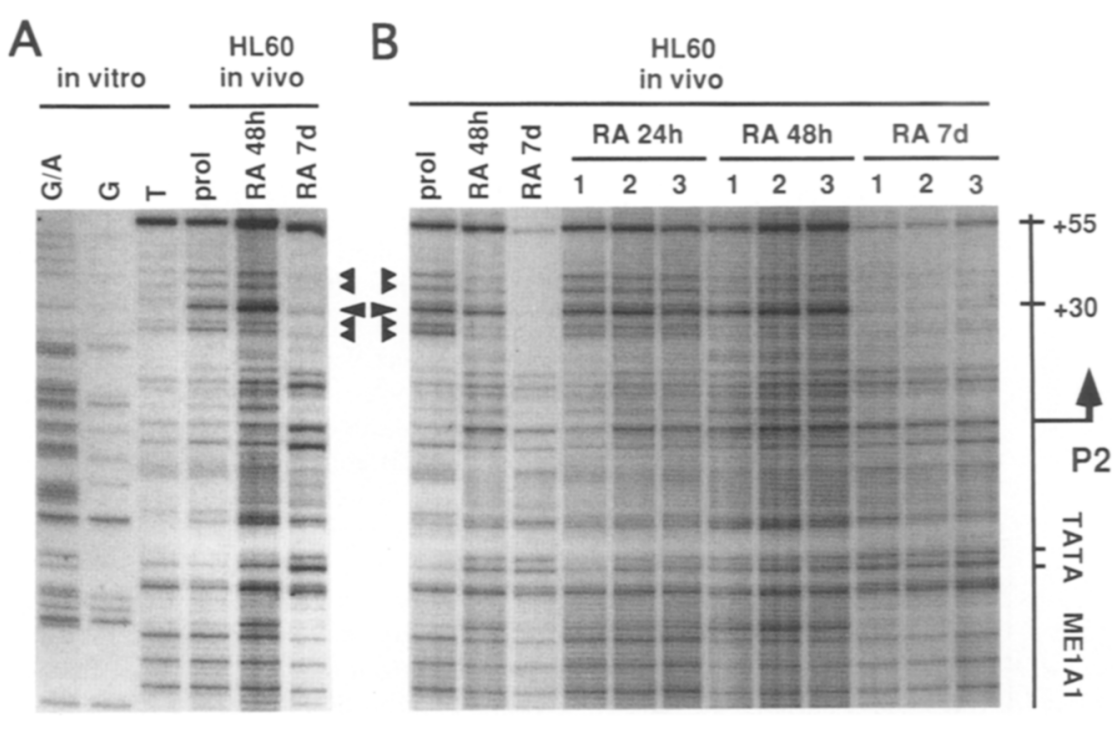

C

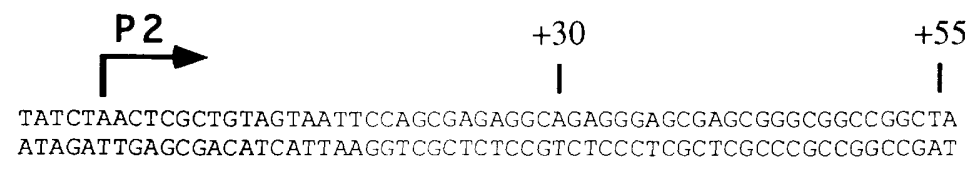

Figure 2. Mapping of potential transcriptional pause sites near the $\mathrm{P} 2$ promoter in vivo. Non-base-paired $T$ residues at +30 downstream of the P2 initiation site are sensitive to $\mathrm{KMnO}_{4}$ in cells containing a transcriptionally active c-myc gene. $(A)$ The in vivo $\mathrm{KMnO}_{4}$ sensitivities of T residues in the template DNA strand of proliferating (prol) HL60 cells and cells differentiated with RA for $48 \mathrm{hr}$ (RA 48h) and 7 days (RA 7d) were compared with DNA treated with $\mathrm{KMnO}_{4}$ in vitro (T). Positions of $\mathrm{KMnO}_{4}$ modifications were determined by comparison to a sequence ladder generated on in vitro-modified, genomic DNA cleaved at $G$ and $A$ residues $(G / A)$, and $G$ (G) residues with formic acid and dimethylsulfate, respectively. Solid arrowheads indicate base residues differentially sensitive in vivo compared with in vitro. $(B) \mathrm{A}$ separate experiment similar to $A$, except that the in vivo-footprinted DNA from cells induced to differentiate with RA for $24 \mathrm{hr}$ (RA 24h) and different times of exposure to $\mathrm{KMnO}_{4}$ are included. Numbers 1,2 , and 3 refer to different exposure times $(1,2$, and $4 \mathrm{~min})$ of $\mathrm{HL} 60$ cells to $\mathrm{KMnO}_{4}$. (C) The DNA sequence and $\mathrm{KMnO}_{4}$-sensitive $\mathrm{T}$ residues within this region are shown. when the run-on assays are performed in high salt (Fig. 3). These results suggest that RNA polymerase II complexes pause in the promoter-proximal region in vivo in both proliferating cells and cells differentiated for $48 \mathrm{hr}$, and that these polymerases are released to elongate in vitro by high salt. This effect cannot be attributed simply to the removal of "roadblocks" such as histones, because $150 \mathrm{mM} \mathrm{KCl}$ is not sufficient to remove histones from DNA (Burton et al. 1978). Run-on experiments were also performed with nuclei of HL60 cells differentiated for 7 days; however, these experiments were not interpretable owing to the low level of transcription in these nuclei (data not shown).

The nuclear run-on assays also reveal that polymerase complexes in differentiated cells are not as processive as those in proliferating cells. Under low salt conditions, the polymerase density does not vary over different regions of exon 1 and intron 1 in nuclei of proliferating cells, whereas in differentiated cells a signal approximatly fivefold higher is observed in the promoter-proximal NS fragment. The high salt nuclear run-on experiments also reveal a difference in the density of transcribing polymerases downstream of +169 in proliferating and differentiated cells (Fig. 3D, cf. the ratios of NS/RS in proliferating and differentiated cells). These results confirm previous observations (Bentley and Groudine 1986; Eick and Bornkamm 1986) that polymerase II transcription complexes in differentiating cells are not as processive as those in proliferating cells. However, in contrast to previous reports, our results suggest that the c-myc elongation block is determined within the region upstream of +169 , rather than at the end of exon 1 . Thus, promoter-proximal sequences appear to be important mediators of the down-regulation of c-myc steadystate RNA levels in differentiating HL60 cells. Nuclear run-on analyses of c-myc transcription in the pluripotent K562 cell line, which contains one copy of the c-myc gene and can be induced to cease proliferation in response to the differentiation agent HMBA, also reveal that polymerase complexes in proliferating cells are more processive than those in induced cells, and RNA polymerase complexes stalled in the promoter-proximal region can be induced to elongate under conditions of high salt (data not shown). Thus, in two different cell lines, the pausing of polymerase in the promoter-proximal region of the c-myc gene accounts fully for the high density of polymerase in exon 1 reported previously.

The addition of $0.6 \%$ Sarkosyl to nuclear run-on assays performed in low (Fig. 3) or high salt (data not shown) also revealed a disproportionately high increase in signal in the promoter-proximal NS fragment in both proliferating and differentiated cells. As described above, these results suggest that polymerase complexes are paused in the promoter-proximal region in vivo, and that these complexes are released to elongate in vitro by Sarkosyl. However, as shown in other systems (O'Brien and Lis 1991), ternary complexes farther downstream are not as efficient in resuming elongation in the presence of Sarkosyl, as indicated by the low RS signal compared with the NS signal in the run-on transcription assays performed with nuclei of proliferating cells (Fig. 3D). This observation suggests that the promoter-proximal 

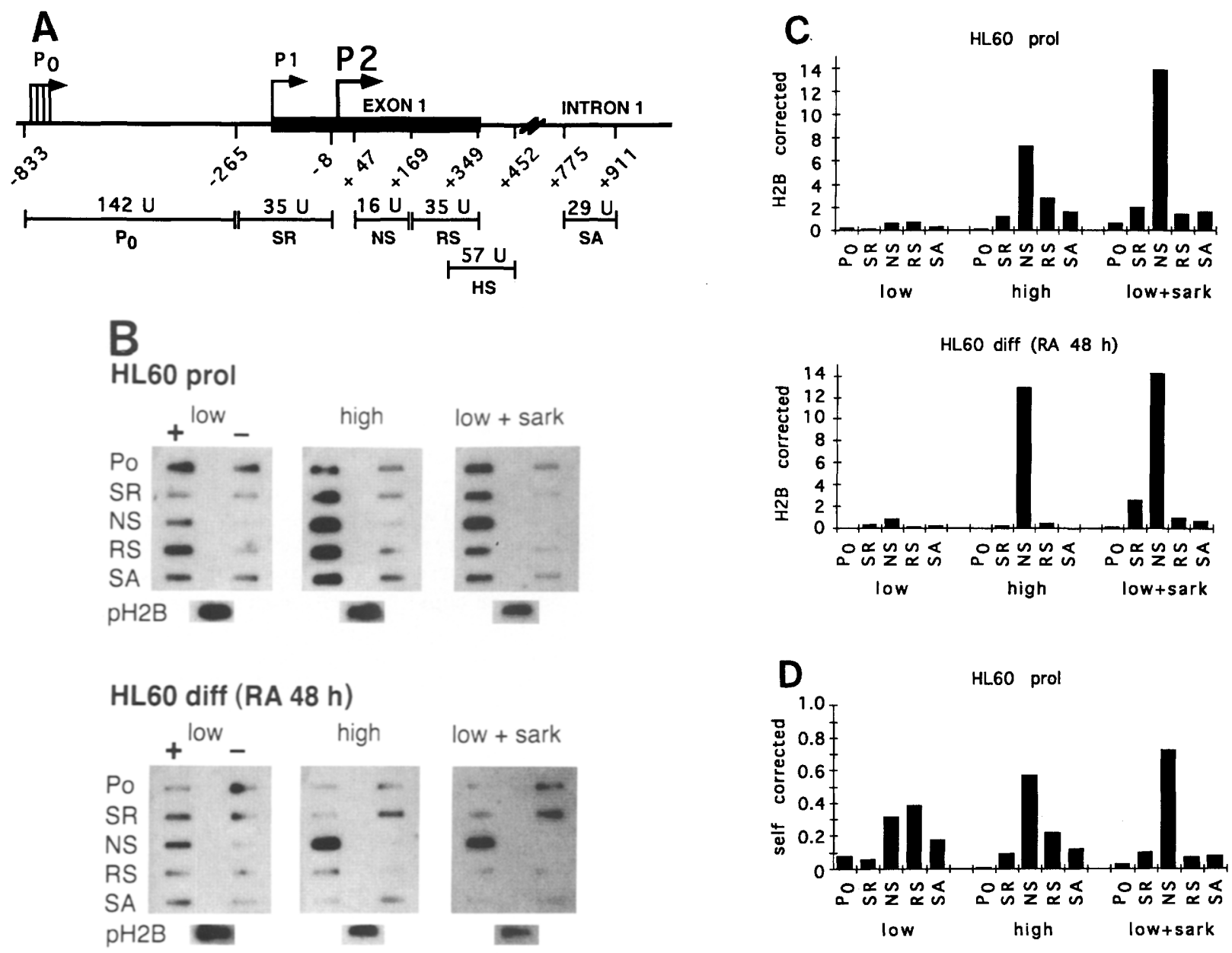

Figure 3. Detection of paused polymerases in nuclear run-on transcription assays. (A) Positions of single-stranded probes used to detect RNA synthesized in nuclear run-ons. (P0, P1, P2) Positions of transcription initiation in the human c-myc gene. The uridine $(U)$ content of transcripts corresponding to individual fragments is shown above each probe. In nuclear run-on experiments with transfected $L$ cells (Fig. 4), an additional probe (HS) was used. (B) Run-on assay with nuclei of proliferating (prol) and differentiating (diff RA $48 \mathrm{~h}$ ) HL60 cells under low (50 $\mathrm{mM} \mathrm{KCl}$ ) and high ( $150 \mathrm{mM} \mathrm{KCl}$ ) salt conditions and in the presence of $0.6 \%$ Sarkosyl. Pulselabeled RNA was hybridized to single-stranded DNA regions containing the antisense $(+)$ and sense $(-) \mathrm{c}$-myc sequences. In control experiments, $\alpha$-amanitin was used to verify that the signal obtained under these conditions is the result of poly-

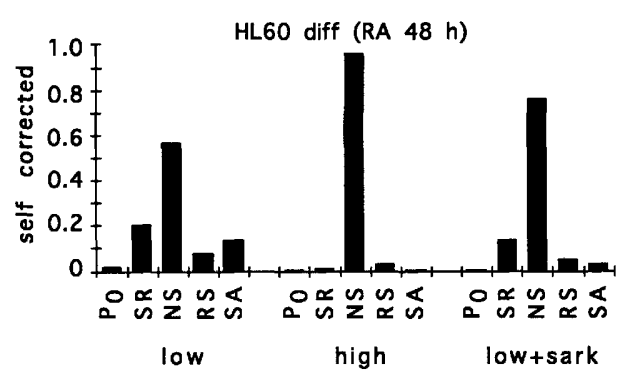
merase II transcription (Bentley and Groudine 1986; data not shown). (pH2B) A probe detecting transcription of the H2B gene. (C), (D) Quantitation of the nuclear run-on shown in B. Signals were scanned and quantified using a PhosphorImager system (Molecular Dynamics|. Background signals were counted separately and subtracted. Values were machine counts of radioactivity bound to immobilized c-myc DNA, corrected for the $U$ content of each probe, and normalized to the signals obtained with the H2B-probe (H2B-corrected graph; $C$ ), or to the sum of signal obtained with the P0, SR, NS, RS, and SA probes (self-corrected graph; D).

polymerase complexes are biochemically distinct from those that have elongated farther into the gene. The use of Sarkosyl in various in vitro transcription assays has also provided evidence for distinct promoter proximal and downstream ternary complexes (Linn and Luse 1991; Kephart et al. 1992).

Polymerase complexes paused in the promoterproximal region are initiated at the $P 2$ promoter

Recently, Xenopus oocyte injection experiments have re- vealed that $3^{\prime}$ ends of transcripts initiated at the upstream P1 promoter can be formed within the P2 promoter (Wright et al. 1991; Meulia et al. 1992; Roberts et al. 1992). Thus, the elongation of polymerase II complexes initiated at the P1 promoter may be "blocked" within the P2 promoter in mammalian cells. Consequently, the observed increase in signal within the promoter-proximal NS fragment after high salt or Sarkosyl treatment of nuclei could be the result of the release of these P1 transcription complexes. To investigate this possibility, we performed nuclear run-on analyses of 
mouse $\mathrm{L}$ cells containing a transfected wild-type human c-myc gene (BS2) or a mutated human c-myc gene $(\Delta \mathrm{P} 1)$ in which the $\mathrm{P} 1$ promoter is deleted and $\mathrm{P} 1$ transcription is abolished (Spencer et al. 1990). As shown in Figure 4, the same pattern of $c-m y c$ transcription was observed in nuclei of transfected polyclones containing the wild-type or $\Delta \mathrm{P} 1 \mathrm{c}-\mathrm{myc}$ gene. Similar to HL60 cells, stalled polymerases were released into the NS fragment when the salt concentration was raised to $150 \mathrm{~mm} \mathrm{KCl}$ or $0.6 \%$ Sarkosyl was added. These results suggest that the high salt/Sarkosyl-induced release of polymerases into the P2 promoter-proximal region is the result of $\mathrm{P} 2$-initiated transcription complexes, rather than $\mathrm{P} 1$-initiated polymerases. It should be noted that in this experiment, the NS signal in the transfected human $c-m y c$ genes is higher than the RS signal under low salt run-on conditions, similar to the results obtained in the differentiated HL60 and K562 cells. In separate experiments, we have observed that the NS/RS ratio varies under low salt conditions in transfected L-cell pools but that the release of polymerases into the NS fragment by high salt or Sarkosyl is invariant (data not shown).

\section{Sequences at the exon/intron boundary} are dispensable for the block to elongation

The nuclear run-on analyses presented above suggest that the promoter-proximal pausing of polymerase complexes accounts fully for the polarity of transcription within the first $c-m y c$ exon reported previously. However, oocyte injection and in vitro transcription analyses have revealed that sequences within the c-myc exon 1 /intron 1 boundary region are sufficient to program 3 '- end formation and termination, respectively, in c-myc and chimeric genes (for review, see Spencer and Groudine 1990,1991; also see Introductory section). To determine whether the intron 1 /exon 1 sequences defined as necessary for 3 -end formation and termination in the oocyte injection and in vitro transcription assays were essential for the block to elongation observed in mammalian cells, a 343-bp deletion from position +269 to +611 was made in the wild-type human c-myc template (Fig. 5A). This construct (pBS2 $\Delta 343$ ) was transfected into mouse L cells, stable polyclones were isolated, and the pattern of c-myc transcription was determined by nuclear run-on analyses (Fig. 5B). Similar to the wild-type c-myc gene, transcription of the deletion mutant under low salt conditions is low and a disproportionate increase in the promoter-proximal signal is observed when the run-on analyses are performed under high salt conditions. Thus, sequences within the exon 1 /intron 1 boundary region do not contribute to the c-myc block to elongation defined by nuclear run-on analyses in mammalian cells.

\section{$c$-myc sequences upstream of position +47 are sufficient to confer the block to elongation}

The $\mathrm{KMnO}_{4}$ sensitivity in both proliferating and differentiating HL60 cells centers around +30 (Fig. 2), and the highest rate of transcription in nuclear run-on assays (Figs. $3-5)$ is observed just downstream $(+47$ to +169$)$. In combination, these data suggest that the sequences upstream of +47 may confer the pausing and Sarkosyl/ high salt release of polymerase. To test this possibility, all c-myc sequences downstream of +47 were replaced
Figure 4. Paused/released polymerases are initiated at the $\mathrm{P} 2$ promoter. Mouse L cells, stably transfected with a wild-type c-myc gene (BS2) and a mutant c-myc gene $(\Delta \mathrm{P} 1)$ containing a 30-bp deletion within the P1 promoter (Spencer et al. 1990) were analyzed in nuclear run-on assays. Control experiments have shown that endogeneous mouse myc transcripts do not crosshybridize to exon 1 and intron 1 sequences of the human c-myc gene (data not shown).
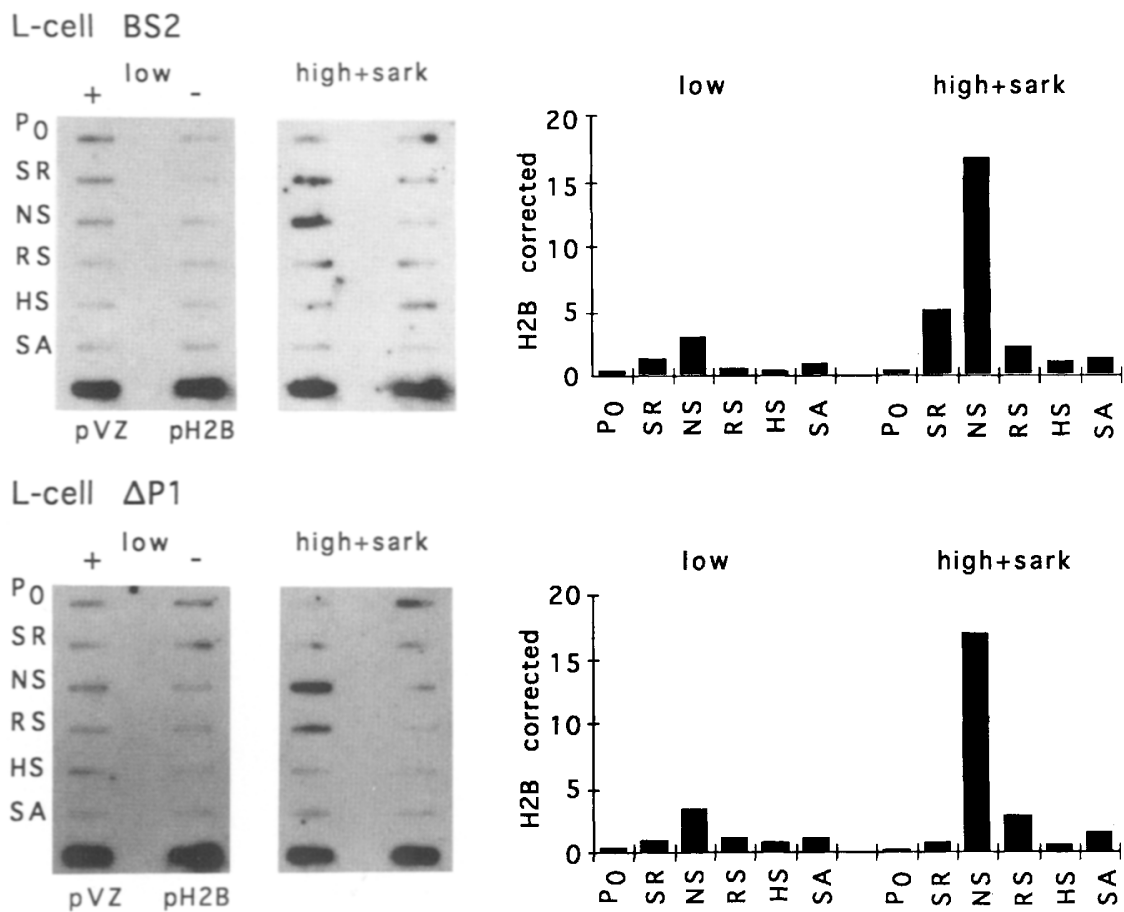

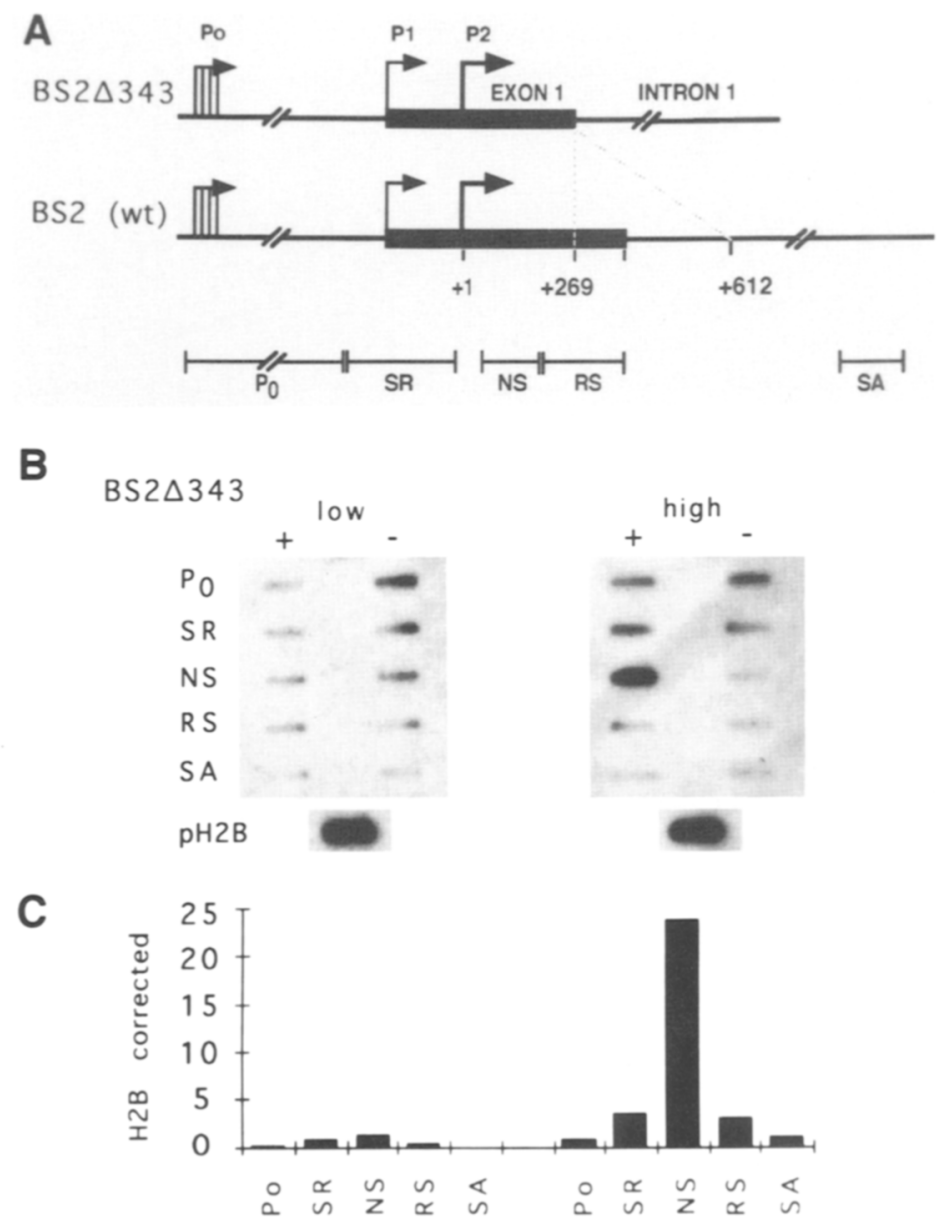

with the bacterial chloramphenicol acetyltransferase (CAT) gene, and this chimeric myc/CAT construct was transfected into mouse $\mathrm{L}$ cells. A control $\mathrm{H} 1^{\circ} / \mathrm{CAT}$ construct (generous gift of L. Johnston and H. Eisen, Fred Hutchinson Cancer Center), consisting of the murine histone $\mathrm{H}^{\circ}$ promoter linked to the same CAT sequences, was also transfected into L cells. In nuclear runon transcription assays performed under low salt conditions, polymerase density does not vary significantly within the $5^{\prime}$ middle and $3^{\prime}$ CAT probes in either construct (Fig. 6). However, when the nuclear run-on assays are performed in the presence of Sarkosyl, a disproportionately high signal is observed in the promoter-proximal CAT sequences (CAT1) in the myc/CAT construct. In contrast, no significant differences in signal are observed within the three CAT probes in nuclei from the $\mathrm{L}$ cell pools containing the $\mathrm{H} 1^{\circ} / \mathrm{CAT}$ gene, under conditions of low salt or Sarkosyl. Therefore, the high density of polymerase in the $5^{\prime}$ CAT sequences observed in the myc/CAT gene in nuclear run-on assays performed in the presence of Sarkosyl is not the result of an intrinsic property of the CAT sequences. These results indicate that c-myc promoter elements, including the first $47 \mathrm{nu}-$ cleotides downstream of the transcription initiation site, are sufficient to cause the promoter-proximal pausing

and high salt/Sarkosyl release of RNA polymerase II transcription complexes.

\section{Release of polymerase complexes results in the loss} of $\mathrm{KMnO}_{4}$ sensitivity at +30

The experiments described above revealed that RNA polymerase II complexes are paused upstream of +169 within the wild-type human c-myc gene and that sequences upstream of +47 are sufficient to program the pausing of polymerase complexes. In addition, mapping of $\mathrm{KMnO}_{4}$ sensitive sites within the transcriptionally active c-myc gene suggests that the pause site is located at +30 . If the release of RNA polymerase II complexes observed in the nuclear run-on assays does, in fact, occur from a pause site at +30 , the $\mathrm{KMnO}_{4}$ sensitivity of the T residue at position +30 should be diminished significantly after the release of polymerase. Thus, we monitored the $\mathrm{KMnO}_{4}$ sensitivity of the c-myc promoterproximal region in isolated nuclei before and after the release of polymerase in high salt nuclear run-on conditions. As shown in Figure 7, hypersensitivity of the T residue at position +30 is observed in nuclei isolated from proliferating HL60 cells, when these nuclei are exposed to $\mathrm{KMnO}_{4}$ before the addition of ribonucleotides 


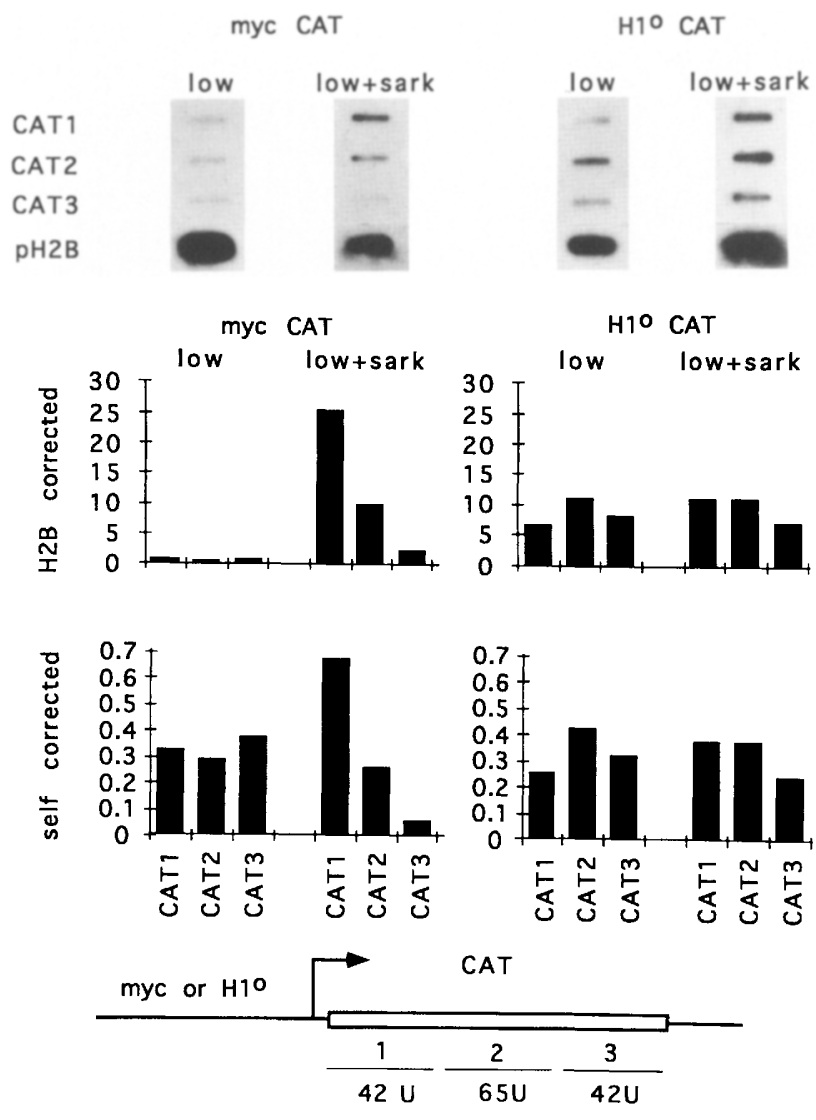

Figure 6. c-myc sequences upstream of +47 are sufficient for the promoter-proximal pausing of polymerase. The myc/CAT and $\mathrm{H}_{1}^{\circ} / \mathrm{CAT}$ constructs containing the human c-myc P2 promoter $(-2489$ to +47 relative to the $\mathrm{P} 2$ start site) or the murine histone $\mathrm{H} 1^{\circ}$ promoter $(-1600$ to +108$)$ upstream of 659 bases of the CAT gene coding sequence (see Materials and methods) were transfected independently with a neomycin resistance gene into mouse L cells, and stably transfected polyclones containing either construct were selected in G418. Nuclear run-on assays were performed with nuclei of polyclonal mouse $\mathrm{L}$ cells containing either the myc/CAT or the $\mathrm{H} 1 \%$ CAT gene, under conditions identical to those described in Fig. 3 . The singlestranded probes used to detect sense transcripts within the CAT sequences correspond to positions -49 to +113 (CAT1), +171 to +393 (CAT2), and +514 to +630 (CAT3), relative to the first base of the CAT AUG initiation codon. The relative position and $U$ content $(\mathrm{CAT} 1=42$, CAT $2=65$ and CAT $3=42)$ of the CAT probes are shown below the line drawing.

(Fig. 7, - NTP lane). Under these conditions, no significant nascent chain elongation occurs (Stallcup et al. 1978). However, hypersensitivity of the T residue at position +30 is not observed when the nuclei are exposed to $\mathrm{KMnO}_{4} 15 \mathrm{~min}$ after the addition of ribonucleotides (Fig. 7, + NTP lane) - conditions in which paused polymerases are released from the promoter-proximal region (Figs. 3-5). Thus, the loss of sensitivity of the $\mathrm{T}$ residue at position +30 to $\mathrm{KMnO}_{4}$ correlates with the release of polymerase from the promoter-proximal region. These results are consistent with a model in which RNA polymerase II complexes are paused at or near postion +30 ; and under conditions of high salt (or Sarkosyl), these complexes are released to elongate.

\section{Discussion}

A combination of $\mathrm{KMnO}_{4}$ and nuclear run-on analyses suggest that RNA polymerase II complexes are paused within the first $47 \mathrm{bp}$ downstream of the $\mathrm{P} 2$ initiation site. Sequences upstream of +47 relative to the P2 initiation site are sufficient to cause the promoter-proximal pausing of polymerase, even when heterologous sequences are cloned downstream of +47 . Thus, the block to $\mathrm{c}-\mathrm{myc}$ elongation in mammalian cells described previously is the result of paused polymerase complexes in the P2 promoter proximal region, rather than at the end of exon 1. P2-initiated polymerases in proliferating cells elongate more efficiently downstream of the promoterproximal region than do polymerase complexes in differentiated cells. In addition, the $\mathrm{KMnO}_{4}$ sensitivity around +30 is distinct in proliferating and 48 -hr-differentiated cells. These results (summarized in Fig. 8) are consistent with a model in which the pausing of polymerase at this promoter-proximal site allows modification of the ternary complex, rendering the complex susceptible or resistant to intrinsic termination signals farther downstream. The nuclear run-on experiments presented above suggest that these termination sites are located upstream of +169 , because the major change upon differentiation of HL60 cells is the decrease in elongating polymerase complexes in the RS fragment $(+169$ to +349$)$ relative to the NS fragment $(+47$ to +169$)$. Although oocyte injection and in vitro transcription assays have shown that a region near the end of exon 1 containing dyad symmetry and two runs of $T$ residues can function as

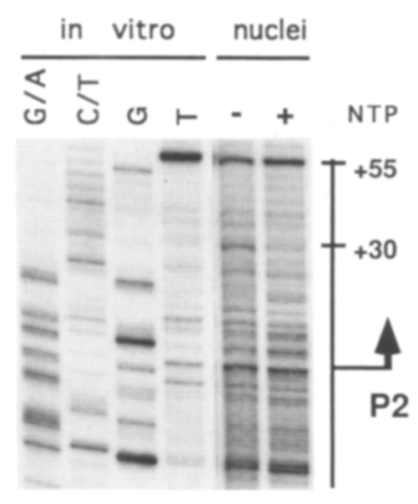

Figure 7. Loss of the $\mathrm{KMnO}_{4}$ sensitivity of the $\mathrm{T}$ residue at position +30 under conditions in which polymerases are released from the promoter-proximal region. Proliferating HL60 nuclei were incubated under high salt $(150 \mathrm{mM} \mathrm{KCl})$ nuclear run-on conditions. Nuclei were exposed to $\mathrm{KMnO}_{4}$ before $(-\mathrm{NTP})$ and $15 \mathrm{~min}$ after $(+\mathrm{NTP})$ the addition of ribonucleoside triphosphates. Genomic DNA exposed to $\mathrm{KMnO}_{4}$ in vitro (T) serves as a control. Positions of residues modified by $\mathrm{KMnO}_{4}$ were determined by comparison to a sequence ladder generated on in vitro-modified genomic DNA cleaved at $G$ and $A(G / A), C$ and $T(C / T)$, and $G(G)$ residues. 


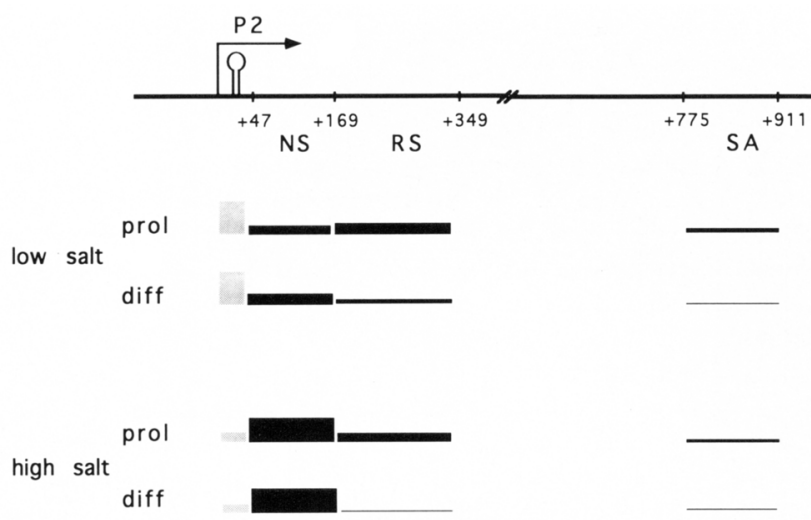

Figure 8. Summary and interpretation of nuclear run-on transcription results. The map coordinates of the various c-myc probes and a stem-loop located from +3 to +25 relative to the P2 start site (see Discussion) are shown. Solid bars represent the density of polymerases within different regions downstream of +47 of the c-myc gene, as measured in nuclear run-on assays. Pausing of polymerases upstream of +47 is indicated by the stippled areas and is deduced from the different results obtained under conditions of low salt, high salt, and Sarkosyl in HL60 and $\mathrm{K} 562$ nuclei and in L cell nuclei containing the BS2 $\Delta 343$ or the myc/CAT fusion gene. Under low salt conditions, the paused promoter-proximal polymerases are not released efficiently into the NS fragment. Under high salt conditions for in the presence of Sarkosyl), these paused polymerases are released. In addition, there are fewer elongating polymerases downstream of +169 in differentiating compared with proliferating cells. In combination, the nuclear run-on and $\mathrm{KMnO}_{4}$ results (Fig. 2) suggest that the polymerase complexes are paused at approximately +30 , and that modification of transcription complexes at this site may be responsible for the differences in elongation efficiencies of polymerase complexes in proliferating and differentiated cells.

efficient termination signals, our deletion analysis demonstrates that this region is dispensable for the c-myc elongation block defined by nuclear run-on transcription assays in mammalian cells. Of potential significance, c-myc 3 ' ends have also been observed upstream of position +169 , both in oocyte injection experiments (Bentley and Groudine 1988) and in vitro (London et al. 1991). Whether these additional sites can function to terminate transcription in vivo remains to be determined.

The mapping of $\mathrm{KMnO}_{4}$ sensitive sites in HL60 cells suggests that the polarity of polymerase density observed under high salt/Sarkosyl nuclear run-on conditions results from the release of RNA polymerase II complexes from position +30 . Consistent with this, sequences downstream of +47 are not required to generate pausing of polymerase II complexes and the polarity of transcription. In addition, the loss of the $\mathrm{KMnO}_{4}$ sensitivity of the $T$ residue at position +30 in isolated nuclei, after RNA polymerase II complexes are released by the addition of ribonucleotides, strongly suggests that the pause site is located at or near +30 . In this context it should be noted that in contrast to the $T$ residue at $+30, T$ residues at positions $+1,+2,+11,+14,+15$, and +26 of the non- coding strand are not sensitive to $\mathrm{KMnO}_{4}$, suggesting further that polymerase complexes are released from the +30 region, rather than from the promoter itself.

The mechanism of pausing of polymerases in the promoter-proximal region of the human c-myc gene is unknown. Recently, in vitro transcription experiments with reconstituted nucleosomal DNA templates revealed that histones can induce or increase pausing of mammalian RNA polymerase II (Izban and Luse 1991). These studies revealed that elongation of RNA polymerase II in vitro through nucleosome-associated DNA is more efficient in the presence of Sarkosyl, which removes histones from DNA, than in the presence of high salt. However, because the release of polymerase complexes in the promoter-proximal region of the c-myc gene is similar in high salt and Sarkosyl, it is unlikely that nucleosome positioning is the basis of the pausing of polymerase in the c-myc promoter-proximal region.

Analysis of transcription in prokaryotes has suggested that GC-rich regions and stem-loop structures may contribute to polymerase pausing (Levin and Chamberlin 1987). Computer analysis of the c-myc P2 promoterproximal sequence reveals a dyad symmetry capable of forming a 7-bp stem and 9-nucleotide loop structure from position +3 through +25 relative to the P2 transcription initiation site, just upstream of the pause site defined by the $\mathrm{KMnO}_{4}$ sensitivity studies and nuclear run-on analyses (Fig. 8). T1 ribonuclease analysis of a synthetic RNA containing these sequences has verified their ability to form a stem-loop in vitro (A. Krumm, unpubl.). Interestingly, this sequence is completely conserved in the murine $c-m y c$ gene.

The pausing of polymerase within the first 47 nucleotides downstream of the P2 initiation site may be similar to the pausing of polymerase at the bacteriophage $\lambda$ qut site at +16 , where, in the presence of $Q$ protein, polymerase is modified into a form that reads through termination signals farther downstream (Roberts 1988). Recently, the E. coli RNA polymerase pause site at qut has been shown to contain single-stranded regions, as defined by $\mathrm{KMnO}_{4}$ sensitivity, both in vitro and in vivo (Kainz and Roberts 1992).

It is also possible that the down-regulation of $\mathrm{c}-\mathrm{myc}$ expression in differentiating cells is accomplished simply by decreasing the frequency of release of ternary complexes paused $5^{\prime}$ to +47 . A similar mechanism has been described for the hsp70 gene in Drosophila, where elements upstream of the transcription initiation site as well as sequences at the +25 pause site contribute to the pausing of RNA polymerase complexes (Lee et al. 1992). The pausing of polymerase at the $h s p 70$ promoter was shown originally by nuclear run-on transcription and UV cross-linking analyses (Gilmour and Lis 1986; Rougvie and Lis 1988). Recently, this pause site has also been mapped by the identification of $\mathrm{KMnO}_{4}$-sensitive sites in the region of +14 through +42 (Giardina et al., this issue). The length of the observed $\mathrm{KMnO}_{4}$-sensitive region suggests that polymerase II complexes may pause at multiple sites in the $h s p 70$ promoter-proximal region. Similarly, we observe multiple $\mathrm{KMnO}_{4}$-sensitive $\mathrm{T}$ resi- 
dues at postion +24 to +40 in the c-myc promoterproximal region, particularly in proliferating cells. These results suggest that the regulation of elongation in the human c-myc and Drosophila hsp70 genes may be through similar mechanisms. Of potential interest, sequences analogous to the GAGA element, which is necessary for the promoter-proximal pausing of polymerase in the $h s p 70$ promoter, are present upstream of the c-myc P2 initiation site. These sequences define the binding site of the MElal protein (Asselin et al. 1989; Pyrc et al. 1992), which has been implicated in the transcription elongation block in the murine c-myc gene (Miller et al. 1989). Interestingly, the human equivalent of this sequence shows consistently less modification by $\mathrm{KMnO}_{4}$ in cells induced with RA (Fig. 2). Thus, the change in reactivity of these residues may be the consequence of a change in DNA conformation mediated by DNA-binding proteins or the protection of DNA by such proteins. Although accessibility of base residues to $\mathrm{KMnO}_{4}$ has been thought to be unaffected by DNA-protein interactions (Borowiec et al. 1987), recent results suggest that this type of protection is possible (Giardina et al., this issue).

Our results are also reminiscent of those described for the regulation of human immunodeficiency virus (HIV) transcription, in which elongation-deficient polymerase complexes are modified into more processive complexes in the promoter-proximal region. The generation of processive RNA polymerase complexes in HIV is mediated through the interaction of Tat protein with the TAR RNA stem-loop element that resides from position +1 to +56 (Kao et al. 1987; Berkhout et al. 1989; Laspia et al. 1989; Selby et al. 1989; Toohey and Jones 1989; Ratnasabapathy et al. 1990; Kato et al. 1992; for reviews, see Jones 1989; Cullen 1990; Rosen 1991; Frankel 1992). In addition, nuclear run-on analyses of several Drosophila genes have revealed that the promoter-proximal pausing of polymerases is a general phenomenon (Rougvie and Lis 1990|. Thus, the modification of ternary complexes at promoter-proximal sites may be an important mechanism in controlling eukaryotic gene expression. Recent in vitro transcription analyses of a number of Drosophila genes have shown that RNA polymerase complexes pause and subsequently terminate during the the initial phase of elongation just after transcription initiation, resulting in the generation of short transcripts (Kephart et al. 1992). The transition from this abortive elongation phase to productive elongation appears to be regulated by both positive and negative factors (Marshall and Price 1992). It will be interesting to determine whether these observations can be extended to mammalian genes, including $c-m y c$, that are regulated by a conditional elongation block.

\section{Materials and methods}

Construction of mutants and M13 clones

The full-length wild-type pBS2 c-myc clone and derivative $\mathrm{p} \Delta \mathrm{P} 1$ c-myc clone from which the P1 TATA box through P1 cap site are deleted have been described previously (Spencer et al. 1990). The pmyc-CAT construct was made by cloning the 2536-bp HindIII-NaeI c-myc promoter fragment $(-2489$ to +47$)$ of $\mathrm{p} \Delta \mathrm{Pl}$ (Spencer et al. 1990) into pBLCAT3 (Luckow and Schutz 1987) containing the bacterial CAT gene and the SV40 polyadenylation region and the small $t$-antigen region. The plasmid pBLCAT3 was cut with XhoI and, after ends were made blunt with T4 polymerase, digested with HindIII. The 343-bp deletion in pBS2 2343 was generated in the human c-myc KpnI-XbaI fragment (from position -1218 to +1019 relative to the P2 transcription initiation site) subcloned into the pBluescript II $\mathrm{SK}|+|$ vector, according to the modified exonuclease III-deletion method of Henikoff (1990). The RsrI-XbaI fragment containing the deletion was inserted into pBS2 (Spencer et al. 1990). The position and extent of the deletion were determined by sequence analysis.

M13 clones of regions of the c-myc gene used as probes for nuclear run-on transcription assays were generated by isolating a 122-bp NaeI-RsrI $1+47$ to +169 relative to the P2 transcription initiation site), a 180 -bp RsrI-PvuII fragment $1+170$ to +349 ), a 192-bp HinfI fragment (+260 to +452$)$, and a 136-bp Sacl-AccII fragment $(+775$ to +911$)$ and inserting them into Ml3mpl8 and Ml3mp19 vectors to obtain the NS, RS, HS, and SA sense and antisense probes. The SR probe was constructed by subcloning a $S m a I-E c o R I$ fragment from pLS13 (Meulia et al. 1992) into M13 vectors.

CAT probes for nuclear run-on assays were constructed by inserting CAT sequences of pCATbasic (Promega) corresponding to -49 to $+113(\mathrm{XbaI}-P$ vuII, CAT 1$),+171$ to +393 (HaeIII, CAT2) and +514 to +630 (MscI-ScaI, CAT3) into Ml3mpl 8 or M13mp19.

\section{Cell lines and transfections}

HL60 cells (for review, see Collins 1987) were maintained in RPMI medium supplemented with $10 \%$ fetal calf serum and 2 mM glutamine. Differentiation of HL60 cells was induced by the addition of RA (Sigma) to a final concentration of $10 \mu \mathrm{M}$.

$L$ cells were grown on petri dishes in Dulbecco's modified Eagle medium (DMEM) with $10 \%$ bovine calf serum. For transfection, $1 \times 10^{7}$ to $2 \times 10^{7}$ cells in DMEM without serum were electroporated in the presence of $15 \mu \mathrm{g}$ of plasmid DNA linearized with $E c o \mathrm{RI}$ (p $\Delta \mathrm{Pl}$ and $\mathrm{pBS} 2)$ or AatII (p $\Delta \mathrm{P} 1 \mathrm{CAT})$ along with pRSV-neo (Gorman et al. 1983). Stably transfected polyclonal lines were established by selection in $1 \mathrm{mg} / \mathrm{ml}$ of G418 for 2 weeks.

\section{In vivo footprinting with $\mathrm{KMnO}_{4}$}

To probe for $\mathrm{KMnO}_{4}$ sensitive sites within the c-myc gene, HL60 cells were harvested and resuspended in medium to a density of $1 \times 10^{7}$ to $2 \times 10^{7} / \mathrm{ml} . \mathrm{KMnO}_{4}$ was added to a final concentration of $10 \mathrm{mM}$, and aliquots of cells were taken at 1,2 , and $4 \mathrm{~min}$ and added immediately to a lysis buffer containing 70 $\mathrm{mm}$ Tris $-\mathrm{HCl}$ (pH 7.4), $2 \mathrm{M} \mathrm{NaCl}, 35 \mathrm{~mm}$ EDTA, 3.5\% SDS, and $0.7 \mathrm{M} \beta$-mercaptoethanol. The $\mathrm{KMnO}_{4}$ treatment of nuclei was conducted as described for whole cells, with the exception that the nuclei were suspended at a concentration of $2 \times 10^{8} / \mathrm{ml}$ in nuclear run-on buffer (Bentley and Groudine 1986) and exposed to $\mathrm{KMnO}_{4}$ at $37^{\circ} \mathrm{C}$ in the presence or absence of ribonucleotides. Genomic DNA was purified with phenol-chloroform and precipitated with ethanol at room temperature. In vitro permanganate modification was performed by treatment of up to $20 \mu \mathrm{g}$ of purified genomic $\mathrm{HL} 60$ DNA in $\mathrm{H}_{2} \mathrm{O}$ with $10 \mathrm{mM} \mathrm{KMnO}_{4}$ (final concentration/ in a $50-\mu \mathrm{l}$ volume for $2 \mathrm{~min}$. The reaction was stopped by the addition of $5 \mu \mathrm{l}$ of $\beta$-mercaptoethanol. DNA 
modified in vitro at $\mathrm{G}$ residues was prepared by the addition of $5 \mu \mathrm{l}$ of $1 \%$ DMS (in ethanol) to $\sim 20 \mu \mathrm{g}$ of genomic DNA in 220 $\mu l 20 \mathrm{~mm}$ Tris- $\mathrm{HCl} / 5 \mathrm{~mm}$ EDTA $(\mathrm{pH} 8)$ for $20 \mathrm{~min}$ at $37^{\circ} \mathrm{C}$. The reaction was stopped by the addition of $50 \mu \mathrm{l}$ of buffer containing $1.5 \mathrm{M}$ sodium acetate $(\mathrm{pH} 7.0)$ and $1 \mathrm{M} \beta$-mercaptoethanol. For G/A and C/T sequence ladders, $20 \mu \mathrm{g}$ genomic DNA in 20 $\mu \mathrm{l}$ was incubated with $25 \mu \mathrm{l}$ of formic acid (G/A) or $30 \mu \mathrm{l}$ hydrazine $(\mathrm{C} / \mathrm{T})$ at room temperature for 4 and $6 \mathrm{~min}$, respectively. Reactions were terminated by the addition of $750 \mu \mathrm{l}$ of a solution containing $0.3 \mathrm{~m}$ sodium actetate $(\mathrm{pH} 7.0), 0.1 \mathrm{mM}$ EDTA, and $25 \mu \mathrm{l} / \mathrm{ml}$ yeast tRNA. DNA was precipitated by the addition of $750 \mu l$ of ethanol. For subsequent cleavage at the modified base residues, DNA was resuspended in $400 \mu \mathrm{l}$ of $\mathrm{H}_{2} \mathrm{O}$, and $400 \mu \mathrm{l}$ of $20 \%$ piperidine was added. After incubation at $94^{\circ} \mathrm{C}$ for $30 \mathrm{~min}$, the tubes were frozen in dry ice. To remove piperidine, the solution was vacuum dried. The DNA was precipitated with ethanol and subjected to the linker/ligation mediated PCR method as described (Mueller and Wold 1989), with the modifications noted below. Primers used to footprint the template strand within the $5^{\prime}$ region of c-myc exon 1 were (1) 5'-TTCCCAAAGCAGAGGGCGTG-3' (position -259 to -240 relative to the P2 initiation site), (2) 5'-AGATCCTCTCTCGCTAATCTCCGC-3' (position -225 to -202 ), and (3) 5'-CCTCTCTCGCTAATCTCCGCCCACCGGC-3' (position -221 to $-194)$. The hybridization temperature for primer 1 was $50^{\circ} \mathrm{C}$, $60^{\circ} \mathrm{C}$ for primer 2 , and $66^{\circ} \mathrm{C}$ for primer 3 . For this primer set, the concentrations of $\mathrm{dNTP}$ and $\mathrm{Mg}^{2}$ ions during the Taq polymerase amplification reaction were at 0.4 and $10 \mathrm{~mm}$, respectively. Primers used to footprint $\mathrm{KMnO}_{4}$ modifications of the coding strand (FP1-FP3) and noncoding strand (GP1-GP3) within the exon 1 /intron 1 boundary region of the $c-m y c$ gene were $F P 1$, 5'-GGTAGTCTTAAAAACCATTCCCG-3' (position +612 to +634 relative to the P2 initiation site); FP2, 5'-CCCGTTTTCCCTCTGCCTTCTCCTCT-3' (position +590 to +615 ); FP3, 5'-CCСTCTGCCTTCTCCTCTCCCATCTTGAC-3' (position +579 to +607$) ;$ GP1, 5'-CACGAAACTTTGCCCATAGC-3' (position + 191 to +210 ); GP2, 5'-GGGCACTTTGCACTGGAACTTACAAC-3' (position + 218 to +243 ); and GP3, 5'TGCACTGGAACTTACAACACCCGAGCAAGG-3' (position +226 to +255 ). The hybridization temperature was $55^{\circ} \mathrm{C}$ for FP1 $64^{\circ} \mathrm{C}$ for $\mathrm{FP} 2,68^{\circ} \mathrm{C}$ for $\mathrm{FP} 3,55^{\circ} \mathrm{C}$ for $\mathrm{GP} 1,61^{\circ} \mathrm{C}$ for $\mathrm{GP} 2$ and $65^{\circ} \mathrm{C}$ for GP3. Only primers used in the final labeling reaction were gel purified. For all footprinting studies, the Sequenase reaction was performed at $37^{\circ} \mathrm{C}$.

\section{Nuclear run-on transcription assays}

Isolation of nuclei from cells lines and nuclear run-on assays were performed as described (Bentley and Groudine 1986), with the following modifications: After the run-on reaction and DNase I treatment of nuclei, RNA was isolated by the RNAzol method: $900 \mu \mathrm{l}$ RNAzol (Cinna/Biotecx) and $90 \mu \mathrm{l}$ of chloroform were added to the run-on reaction and vortexed vigorously. The nucleic acids were subsequently recovered by precipitation with one volume of isopropanol. Unincorporated nucleotides were removed by use of a Sephadex G50 spin column or two additional ethanol precipitations. After hybridization to filterbound, single-stranded DNA probes, GeneScreen filters were treated at $30^{\circ} \mathrm{C}$ for $30 \mathrm{~min}$ with $10 \mu \mathrm{g} / \mathrm{ml}$ of RNase $A$ in $2 \times S S C$ $(0.3 \mathrm{M} \mathrm{NaCl}, 0.03 \mathrm{M}$ sodium acetate) and then washed twice in $0.1 \times \mathrm{SSC} / 1 \% \mathrm{SDS}$ at $65^{\circ} \mathrm{C}$. Filters were exposed to storage phosphor screens and scanned and quantified with a PhosphorImager system (Molecular Dynamics).

\section{Acknowledgments}

We thank David Dickey for excellent assistance in the trans- fection experiments and growth of cells and Mary Peretz for excellent technical assistance in the construction and verification of probes used in the nucelar run-on experiments. We thank our colleagues in the Groudine laboratory and Fred Hutchinson Cancer Center Research for their comments during the course of these experiments, and L. Johnston and H. Eisen for the $\mathrm{H} 1 \%$ CAT construct. We also thank John Lis for suggestions concerning this manuscript and communicating unpublished information from his own laboratory, and J. Gralla for discussions concerning the $\mathrm{KMnO}_{4}$ data. This work was supported by National Cancer Institute grants CA54337 and CA57156 to M.G., Deutsche Forschungsgemeinschaft (DFG), and Leukemia Research Foundation fellowships to A.K. and a Swiss National Foundation fellowship to T.M.

The publication costs of this article were defrayed in part by payment of page charges. This article must therefore be hereby marked "advertisement" in accordance with 18 USC section 1734 solely to indicate this fact.

\section{Note added in proof}

After this manuscript was in press, L.J. Strobl and D. Eick published nuclear run-on experiments that confirm the observation that a high density of polymerase II in the promoter-proximal region accounts for the excess of c-myc exon 1 transcription in HL-60 cells (Strobl and Eick 1992). Hold-back of RNA polymerase II at the transcription start site mediates down-regulation of c-myc in vivo. (EMBO J. 11:3307-3314).

\section{References}

Asselin, C., A. Nepveu, and K.B. Marcu. 1989. Molecular requirements for transcriptional initiation of the murine c-myc gene. Oncogene 4: 547-558.

Ben-Aser, E. and Y. Aloni. 1984. Transcription of minute virus of mice, an automous parvovirus, may be regulated by attenuation. I. Virol. 52: 266-276.

Bentley, D.L. and M. Groudine. 1986. A block to elongation is largely responsible for decreased transcription of c-myc in differentiated HL60 cells. Nature 321: 702-706.

- 1988. Sequence requirements for premature termination of transcription in the human c-myc gene. Cell 53: 245-256.

Berkhout, B., R.H. Silverman, and K. Jeang. 1989. Tat transactivates the human immunodeficiency virus through a nascent RNA target. Cell 59: 273-282.

Borowiec, J.A., L. Zhang, S. Sasse-Dwight, and J.D. Gralla. 1987. DNA supercoiling promotes formation of a bent repression loop in lac DNA. J. Mol. Biol. 196: 101-111.

Burton, D.R., M.J. Butler, J.E. Hyde, D. Philips, C.J. Skidmore, and I.O. Walker. 1978. The interaction of core histones with DNA: Equilibrium binding studies. Nucleic Acids Res. 5: 3643-3663.

Collins, S.J. 1987. The HL60 promyelocytic leukemia cell line: proliferation, differentiation, and cellular oncogene expression. Blood 70: 1233-1244.

Collins, S.J. and M. Groudine. 1982. Amplification of endogenous myc-related DNA sequences in a human myeloid leukemia cell line. Nature 298: 679-682.

Cullen, B.R. 1990. The HIV-1 Tat protein: An RNA sequence specific processivity factor? Cell 63: 655-657.

Dalla-Favera, R., F. Wong-Staal, and R. Gallo. 1982. Onc gene amplification in promyelocytic cell line HL60 and primary leukemia cells of the same patient. Nature 299: 61-63.

Eick, D. and G.W. Bornkamm. 1986. Transcriptional arrest within the first exon is a fast control mechanism in the 
c-myc gene expression. Nucleic Acids Res. 14: 8331-8345.

Frankel, A.D. 1992. Activation of HIV transcription by Tat. Curr. Opin. Genet. Dev. 2: 293-298.

Gilmour, D.S. and J.T. Lis. 1986. RNA polymerase II interacts with the promoter region of the non-induced hsp 70 gene in Drosophila melanogaster cells. Mol. Cell. Biol. 6:3984 3989.

Gorman, C.R., R. Padmanabdhan, and B. Howard. 1983. High efficiency DNA-mediated transformation of primate cells. Science 221: 551-553.

Hay, N., D.H. Skolnik, and Y. Aloni. 1982. Attenuation in the control of SV40 gene expression. Cell 29: 183-193.

Henikoff, S. 1990. Ordered deletions for DNA sequencing and in vitro mutagenesis by polymerase extension and exonuclease III gapping of circular templates. Nucleic Acids Res. 18: $2961-2966$.

Izban, M.G. and D.S. Luse. 1991. Transcription on nucleosomal templates by RNA polymerase II in vitro: Inhibition of elongation with enhancement of sequence-specific pausing. Genes \& Dev. 5: 683-696.

Jones, K.A. 1989. HIV trans-activation and transcription control mechanisms. New Biol. 1: 127-135.

Kainz, M. and J. Roberts. 1992. Structure of transcription elongation complexes in vivo. Science 255: 838-841.

Kao, S.Y., A.F. Calman, P.A. Luciw, and B.M. Peterlin. 1987. Anti-termination of transcription within the long terminal repeat of HIV-1 by tat gene product. Nature 330: 489-493.

Kassavetis, G.A., B.R. Braun, L.H. Nguyen, and E.P. Geiduschek. 1990. S. cerevisiae TFIIIB is the transcription initiation factor proper of RNA polymerase III, while TFIIIA and TFIIIC are assembly factors. Cell 60: 235-245.

Kato, H., H. Simimoto, P. Pognonec, C.H. Chen, C.A. Rosen, and G.R. Roeder. 1992. HIV-1 Tat acts as a processivity factor in vitro in conjunction with cellular elongation factors. Genes \& Dev. 6: 655-666.

Kephart, D.D., N.F. Marshall, and D.H. Price. 1992. Stability of Drosophila RNA polymerase II elongation complexes in vitro. Mol. Cell. Biol. 12: 2067-2077.

Kerppola, T.K. and C.M. Kane. 1988. Intrinsic sites of transcription termination and pausing in the c-myc gene. Mol. Cell. Biol. 8: 4389-4394.

Laspia, M.F., A.P. Rice, and M.B. Mathews. 1989. HIV-1 Tat protein increases transcriptional initiation and stabilizes elongation. Cell 59: 283-292.

Lee, H., K.W. Kraus, M.F. Wolfner, and J.T. Lis. 1992. DNA sequence requirements for generating paused polymerase at the start of hsp70. Genes \& Dev. 6: 284-295.

Levin, J.R and M.J. Chamberlin. 1987. Mapping and characterization of transcriptional pause sites in the early genetic region of bacteriophage T7. J. Mol. Biol. 196: 61-84.

Linn, S.C. and D.S. Luse. 1991. RNA polymerase II elongation complexes paused after the synthesis of 15- or 35-base transcripts have different structures. Mol. Cell. Biol. 11: 15081522.

London, L., R.G. Keene, and R. Landick. 1991. Analysis of premature termination in c-myc during transcription by RNA polymerase II in HeLa nuclear extract. Mol. Cell. Biol. 11: 4599-4615.

Luckow, B. and G. Schutz. 1987. CAT constructions with multiple unique restriction sites for the functional analysis of eukaryotic promoters and regulatory elements. Nucleic Acids Res. 15: 5490.

Maderious, A. and S. Chen-Kiang. 1984. Pausing and premature termination of human RNA polymerase during transcription of Adenovirus in vivo and in vitro. Proc. Natl. Acad. Sci. 81: 5931-5935.
Marshall, N.F. and D.H. Price. 1992. Control of formation of two distinct classes of RNA polymerase II elongation complexes. Mol. Cell. Biol. 12: 2078-2090.

Meulia, T., A. Krumm, C. Spencer, and M. Groudine. 1992. Sequences in the human c-myc P2 promoter affect the elongation and premature termination of transcripts initiated in the upstream P1 promoter. Mol. Cell. Biol. (in press).

Miller, H., C. Asselin, D. Dufort, J.Q. Yang, K. Gupta, K.B. Marcu, and A. Nepveu. 1989. A cis-acting element in the promoter region of the murine c-myc gene is necessary for transcriptional block. Mol. Cell. Biol. 9: 5340-5349.

Mueller, P.R. and B. Wold. 1989. In vivo footprinting of a muscle specific enhancer by ligation mediated PCR. Science 246: $780-785$.

Nepveu, A. and K.B. Marcu. 1986. Intragenic pausing and antisense transcription within the murine c-myc locus. $E M B O F$. 5: 2859-2865.

O'Brien, T. and J.T. Lis. 1991. RNA polymerase II pauses at the $5^{\prime}$ end of the transcriptionally induced Drosophila hsp70 gene. Mol. Cell. Biol. 11: 5285-5290.

O'Halloran, T.V., B. Frantz, M.K. Shin, D.M. Ralston, and J.G. Wright. 1989. The MerR heavy metal receptor mediates positive activation in a topologically novel transcription complex. Cell 56: 119-129.

Platt, T. 1986. Transcription termination and the regulation of gene expression. Annu. Rev. Biochem. 55: 339-372.

Pyrc, J.J., K.H. Moberg, and D.J. Hall. 1992. Isolation of a novel cDNA encoding a zinc-finger protein that binds to two sites within the c-myc promoter. Biochemistry 31: 4102-4110.

Ratnasabapathy, R., M. Sheldon, L. Johal, and N. Hernandez. 1990. The HIV-1 long terminal repeat contains an unusual element that induces the synthesis of short RNAs from various mRNA and snRNA promoters. Genes \& Dev. 4: 20612074.

Roberts, J.W. 1988. Phage lambda and the regulation of transcription termination. Cell 52: 5-6.

Roberts, S., T. Purton, and D.L. Bentley. 1992. A protein binding site in the c-myc promoter functions as a terminator of RNA polymerase II transcription. Genes \& Dev. 6: 1562-1574.

Rosen, C.A. 1991. Regulation of HIV gene expression by RNAprotein interaction. Trends Genet. 7: 9-14.

Rougvie, A.E. and J.T. Lis. 1988. The RNA polymerase II at the 5 ' end of the uninduced hsp 70 gene of the D. melanogaster is transcriptionally engaged. Cell 54: 795-804.

- 1990. Postinitiation transcriptional control in Drosophila melanogaster. Mol. Cell. Biol. 10: 6041-6945.

Sasse-Dwight, S. and J.D. Gralla. 1988. Probing the Escherichia coli glnALG upstream activation mechanism in vivo. Proc. Natl. Acad. Sci. 85: 8934-8938.

- 1989. $\mathrm{KMnO}_{4}$ as a probe for lac promoter melting and mechanism in vivo. J. Biol. Chem. 264: 8074-8081.

. 1990. Role of eukaryotic-type functional domains found in the prokaryotic enhancer receptor factor sigma 54 . Cell 62: $945-954$

Selby, M.J., E.S. Bain, P.A. Luciw, and B.M. Peterlin. 1989. Structure, sequence, and position of the stem-loop in tar determine transcriptional elongation by tat through the HIV-1 long terminal repeat. Genes \& Dev. 3: 547-558.

Siebenlist, U., P. Bressler, and K. Kelly. 1988. Two distinct mechanisms of transcriptional control operate on c-myc during differentiation of HL60 cells. Mol. Cell. Biol. 8: 867-874.

Spencer, C.A. and M. Groudine. 1990. Transcription elongation and eukaryotic gene regulation. Oncogene 5: 777-785.

1991. Control of c-myc regulation in normal and neoplastic cells. Adv. Cancer Res. 56: 1-47.

Spencer, C.A., R.C. LeStrange, U. Novak, W.S. Hayward, and M. 
Groudine. 1990. The block to transcription elongation is promoter dependent in normal and Burkitt's lymphoma c-myc alleles. Genes \& Dev, 4: 75-88.

Stallcup, M.R., J. Ring, and K. Yamamoto. 1978. Synthesis of mouse mammary tumor virus ribonucleic acid in isolated nuclei from cultured mammary tumor cells. Biochemistry. 17: 1515-1521.

Toohey, M.G. and K.A. Jones. 1989. In vitro formation of short RNA polymerase II transcripts that terminate within the HIV - 1 and HIV-2 promoter-proximal downstream regions. Genes \& Dev. 3: 265-282.

Vos, J.C., M. Sasker, and H.G. Stunnenberg. 1991: Promoter melting by a stage-specific vaccinia virus transcription factor is independent of the presence of RNA polymerase. Cell 65: $105-113$.

Wang, W., M. Carey, and J.D. Gralla. 1992. Polymerase II promoter activation: Closed complex formation and ATPdriven start site opening. Science 255: 450-453.

Wright, S., L.F. Mirels, M.C. Calayag, and J.M. Bishop. 1991. Premature termination of transcription from the P1 promoter of the mouse c-myc gene. Proc. Natl. Acad. Sci. 88: 11383-11387.

Yanofsky, C. 1988. Transcription attenuation. J. Biol. Chem. 263: 609-612.

Zhang, L. and J.D. Gralla. 1989. In situ nucleoprotein structure at the SV40 major late promoter: Melted and wrapped DNA flank the start site. Genes \& Dev. 3: 1814-1822. 


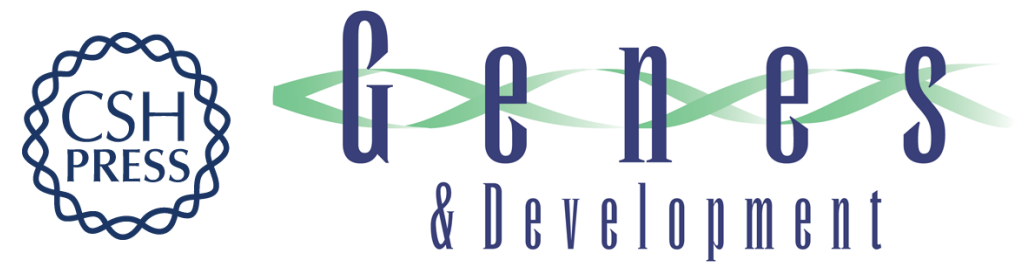

\section{The block to transcriptional elongation within the human c-myc gene is determined in the promoter-proximal region.}

A Krumm, T Meulia, M Brunvand, et al.

Genes Dev. 1992, 6:

Access the most recent version at doi:10.1101/gad.6.11.2201

References This article cites 61 articles, 30 of which can be accessed free at:

http://genesdev.cshlp.org/content/6/11/2201.full.html\#ref-list-1

License

Email Alerting Receive free email alerts when new articles cite this article - sign up in the box at the top Service right corner of the article or click here.

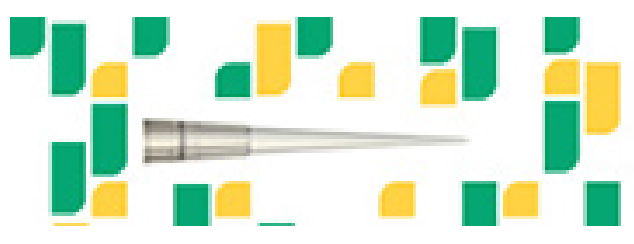

Focused on your science. 